This is the final peer-reviewed accepted manuscript of

Rossi, Veronica; Azzarone, Michele; Capraro, Luca; Faranda, Costanza; Ferretti, Patrizia; Macrì, Patrizia;

Scarponi, Daniele: Dynamics of benthic marine communities across the Early-Middle Pleistocene boundary in the Mediterranean region (Valle di Manche, Southern Italy): Biotic and stratigraphic implications.

PALAEOGEOGRAPHY PALAEOCLIMATOLOGY PALAEOECOLOGY, 495. 0031-0182

DOI: $10.1016 /$ j.palaeo.2017.12.042

The final published version is available online at:

http://dx.doi.org/10.1016/j.palaeo.2017.12.042

Rights / License:

The terms and conditions for the reuse of this version of the manuscript are specified in the publishing policy. For all terms of use and more information see the publisher's website.

This item was downloaded from IRIS Università di Bologna (https://cris.unibo.it/)

When citing, please refer to the published version. 


\title{
Dynamics of benthic marine communities across the Early-Middle Pleistocene boundary in the Mediterranean region (Valle di Manche, Southern Italy): Biotic and stratigraphic implications
}

\author{
Veronica Rossi $^{\mathrm{a}}$, Michele Azzarone ${ }^{\mathrm{a}}$, Luca Capraro ${ }^{\mathrm{b}}$, Costanza Faranda ${ }^{\mathrm{c}}$, Patrizia Ferretti ${ }^{\mathrm{d}}$, \\ Patrizia Macrì ${ }^{\mathrm{e}}$, Daniele Scarponi ${ }^{\mathrm{a}, *}$ \\ ${ }^{a}$ Dipartimento di Scienze Biologiche, Geologiche e Ambientali, University of Bologna, Piazza di Porta San Donato 1, I-40126 Bologna, Italy \\ b Dipartimento di Geoscienze, University of Padova, Via G. Gradenigo 6, I-35131 Padova, Italy \\ ${ }^{\mathrm{c}}$ Dipartimento di Scienze, University of Roma Tre, Largo San Leonardo Murialdo 1, 00146 Roma, Italy \\ d Consiglio Nazionale delle Ricerche, Istituto per la Dinamica dei Processi Ambientali (CNR-IDPA), Via Torino 155, I-30172 Venezia Mestre, Italy \\ e Istituto Nazionale di Geofisica e Vulcanologia, Via di Vigna Murata 605, I-00143 Roma, Italy
}

\section{A R T I C L E I N F O}

Keywords:

Stratigraphic Paleobiology

Early-Middle Pleistocene boundary Ordination

analysis

Glacial-Interglacial cycles Ostracod Mollusk

\begin{abstract}
A B S T R A C T
The Valle di Manche (VdM) section (Calabria, Southern Italy) offers the opportunity to investigate the ostracod turnover along a continuous shelf succession straddling the Early-Middle Pleistocene boundary, and compare it against other paleoenvironmental (i.e., mollusks) and paleoclimatic (Uvigerina peregrina $\delta^{18} \mathrm{O}$ ) records. Highresolution (ca. 1 sample/m) ostracod fauna quantitative data, coupled with gradient analysis (Detrended Correspondence Analysis and non-Metric Multi-Dimensional Scaling), document a strong relationship between changes in faunal composition and lithofacies vertical stacking patterns. The comparison between the molluskand ostracod-derived ordination data demonstrates that the meio- and macro-faunal turnover is guided by a common complex gradient: bathymetry. The integrated ostracod-mollusk gradient analysis also provides a trend in water depths along the section, highlighting to what extent such multivariate approach can improve the paleoenvironmental and sequence stratigraphic interpretation of ancient shallow marine successions. When plotted stratigraphically, ordination major axis sample scores reveal two increasing-decreasing patterns in water depth that fit well with the T-R cycles previously identified. Paleobathymetric estimates combined with the vertical distribution of key ostracod groups (i.e., epiphytic taxa on sandy substrates vs. deep-sea mud related taxa) allow refining depositional trends, stratal stacking patterns and position of previously not well resolved sequence stratigraphic surfaces within each T-R cycle (e.g., Transgressive Surface-TS). Indeed, two rapid in-creases in water depth values mark the TSs that separate shallowing-upward, progradational (RST) from dee-pening upward, retrogradational (TST) stratal stacking patterns of shelf deposits. The TSs, which underline fine-grained successions dominated by deep-sea mud-lover taxa, are invariably constrained to the inception of in-terglacials Marine Isotope Stages (MIS) 21 and 19, identified within the VdM section by benthic foraminifera $\delta^{18} \mathrm{O}$ values. Within both the VdM T-R cycles, the deepest conditions (ca. $140 \mathrm{~m}$ of water depth) are invariably identified within the Neopycnodonte unit, slightly above the lightest $\delta^{18} \mathrm{O}$ intervals. The overlying decreasing bathymetric trend, coupled with shifts in ostracod ecological groups, allows to identify in the bryozoans li-thofacies the stillstand + falling of the relative sea-level, also tracked by a progressively heavier $\delta^{18} \mathrm{O}$ record. More stable paleobathymetric conditions (around 40-45 $\mathrm{m}$ of water depth) characterize the overlying silt-sand deposits dominated by epiphytic species and showing the heaviest $\delta^{18} \mathrm{O}$ values.
\end{abstract}

\section{Introduction}

During the last decades, the value of marine benthic fauna and re lated traces as paleoenvironmental and paleoclimatic proxy has been exploited in several Quaternary and pre Quaternary successions (e.g.
Murray, 2006; Baucon et al., 2012; Horne et al., 2012; Horton et al., 2013; Ávila et al., 2015; Gliozzi et al., 2015; Huntley and Scarponi, 2015; Bruno et al., 2017). Specifically, the distribution of ostracods in almost every aquatic depositional settings and their good ecological sensitivity to changing environmental conditions make these small

\footnotetext{
* Corresponding author.

E-mail address: daniele.scarponi@unibo.it (D. Scarponi).
} 
crustaceans ( 0.4 to $2.0 \mathrm{~mm}$ on average) a routinely employed tool in paleoenvironmental reconstructions from continental to marine settings (e.g., Bonaduce et al., 1975; Henderson, 1990; Montenegro and Pugliese, 1996; Faranda et al., 2007; Pascual et al., 2008; Marriner and Morhange, 2007; Bini et al., 2012; Marco Barba et al., 2013a, 2013b; Grossi et al., 2015; Martinez Garcia et al., 2015; Mazzini et al., 2015, 2017; Pint et al., 2015). Recent studies have also documented the ostracod capability to track high frequency and high energy depositional events (paleofloods) in the marine realm (Angue Minto'o et al., 2015; Barbieri and Vaiani, 2018; Fanget et al., 2016). In contrast, minor at tention has been paid on the relevance of marine ostracods in identifying stratal stacking patterns and depositional trends in a sequence stratigraphic perspective, also with respect to other biological proxies (e.g., Yasuhara et al., 2012; Amorosi et al., 2014a).

Through time, a series of Plio Pleistocene open marine sections outcropping in Southern Italy and considered of great significance for the chronostratigraphy of the Quaternary period (i.e., Monte San Nicola, Vrica, Montalbano Jonico and Fronte sections), were analyzed for the ostracod fauna to improve paleoenvironmental reconstructions (Colalongo and Pasini, 1980; Aiello et al., 2000, 2015; Amorosi et al., 2014b). Changes in paleobathymetry and dissolved oxygen/food availability are likely to represent the main drivers of the ostracod turnover in these sections (e.g., Aiello et al., 2015; Marino et al., 2015; Negri et al., 2015). The on land marine Valle di Manche section (Calabria, Southern Italy; Fig. 1A B) preserves a detailed and time constrained history of climate evolution and sea level variability across the Early Middle Pleistocene transition based on a multi proxy re construction (Scarponi et al., 2014; Head and Gibbard, 2015; Capraro et al., 2017). However a detailed ostracod investigation is currently lacking, notwithstanding the section has high potential for paleoenvironmental studies.

The Valle di Manche (VdM) section represents an ideal venue where to investigate the main driver(s) of ostracod turnover and test ostracods capacity of tracking environmental changes, as its tens $\mathrm{m}$ thick succession of marine deposits is firmly constrained in time (Early Middle Pleistocene transition; Rio et al., 1996; Fig. 1B). In addition, a quasi continuous, high resolution record of benthic foraminifera $\delta^{18} \mathrm{O}$ values $\left(\delta^{18} \mathrm{O}\right.$ Uvigerina peregrina) offers a well defined framework of Milanko vitch climate eustatic variability (from late MIS 22 to early MIS 18 Fig. 2, Capraro et al., 2005, 2017). Lastly the reconstruction of macrobenthic turnover and derived paleobathymetric quantitative estimates (Scarponi et al., 2014), from the same stratigraphic profile, fur nish the rare opportunity to compare ostracod dynamics against a different paleoecological proxy into a shelf setting. In this respect, distinct benthic groups (i.e., mollusks and ostracods) may show differential response to the drivers of environmental change, because of differences in their ecological requirements.

The main purpose of this study is to describe the vertical distribution patterns of ostracods across the middle portion of the VdM section (Fig. 2) to (i) evaluate if ecologically different and widely used proxies as ostracods and mollusks show comparable turnover along the same sedimentary record or if they respond to different driver(s) of environmental change and (ii) highlight to what extent ostracod quantitative analyses can improve and refine the VdM stratigraphic and paleonvironmental framework (e.g., biofacies characterization and stratal stacking patterns). Indeed, integrated investigations involving multiple environmental proxies have the greatest potential to increase our understanding of biotic responses to environmental changes, meanwhile allowing for a clearer reconstruction of the stratigraphic architecture of sedimentary successions (e.g., Amorosi et al., 2014a; Rossi et al., 2017).

\section{Geological setting}

\subsection{The Crotone Basin}

The Crotone Basin (CB hereafter, Calabria, Southern Italy; Fig. 1A) is located above the internal part of the Calabrian accretionary wedge (Rossi and Sartori, 1981) and hosts a remarkably thick, well exposed and highly fossiliferous succession, upper Miocene to Pleistocene in age. As the San Mauro Marchesato confined sub basin, within the central sector of the CB (Fig. 1A), has been affected by high subsidence related to tectonic activity (see Van Dijk, 1994; Speranza et al., 2011; Macrì et al., 2014), marine sedimentation lasted till the Middle Pleis tocene (Capraro et al., 2006; Massari et al., 2010). Within the in vestigated sub basin, the upper tectono stratigraphic unit (San Mauro Sandstone unit of Roda, 1964) was further subdivided (Rio et al., 1996) into three sub units (SM1 to SM3) that can be conveniently traced across the San Mauro sub basin and in part across the VdM section (Fig. 1B).

The SM2 unit, ca. 5 to $40 \mathrm{~m}$ thick, spans from the uppermost MIS 22 to the full MIS 18.4 glacial (Capraro et al., 2005, 2017; Fig. 1B). It consists of grayish, prominent packages of marine deposits ranging from muds to sandy silts, which reflect a series of deepening and shallowing trends between "fully glacial sand packages" pertaining to MIS 24/22 and MIS 18. Indeed, stratal geometries of the SM2 point to a major increase in tectonic subsidence rates, which emphasized the glacioeustatic sea level rise after the MIS 24/22 glaciation (Capraro et al., 2005). The overlying unit (SM3, Middle Pleistocene) is characterized by thick sandstone/conglomerate bodies showing a distinct shallowing upward trend, predating the definitive uplift of the sub-

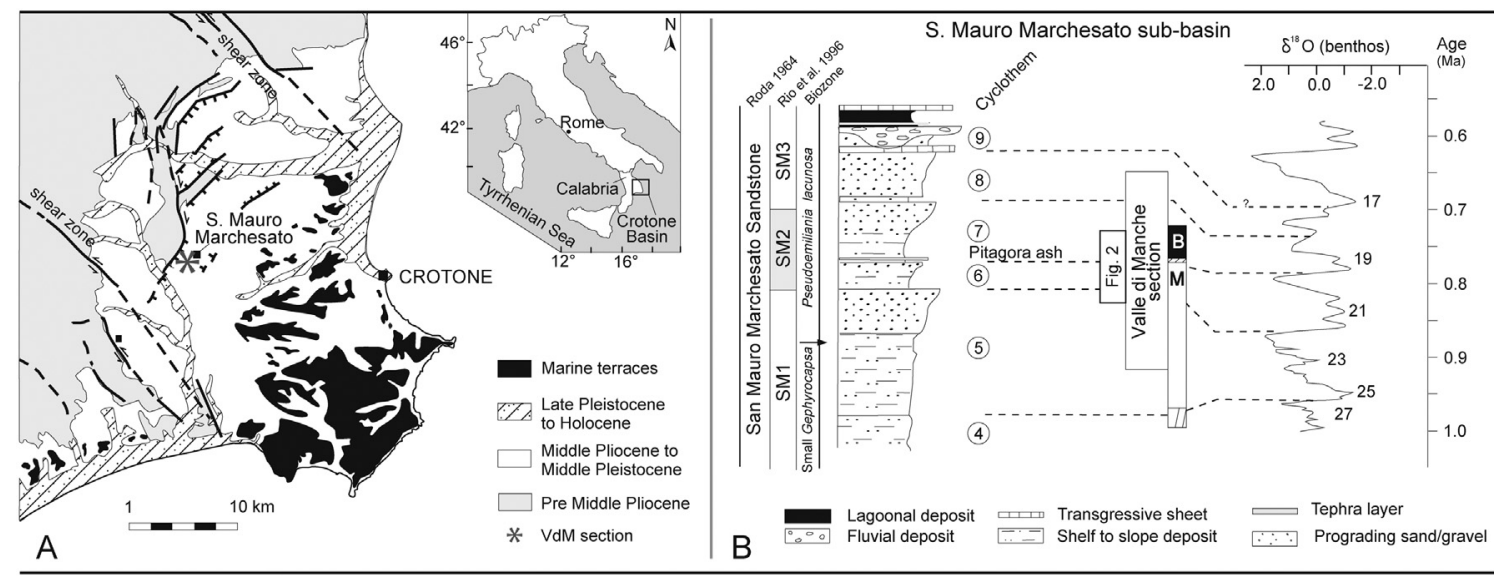

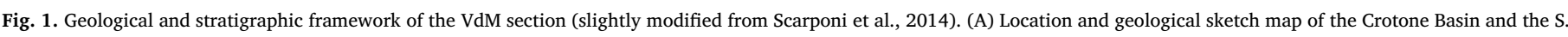

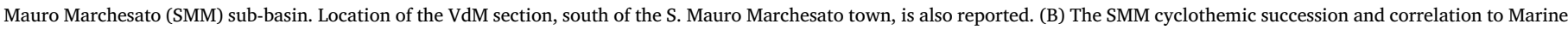

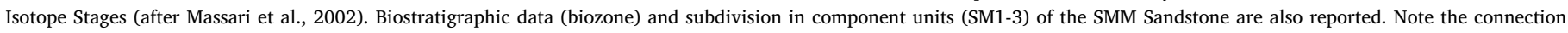
between the Matuyama-Brunhes geomagnetic reversal (mid MIS 19) and the Pitagora ash layer. B: Brunhes chron; M: Matuyama chron. 


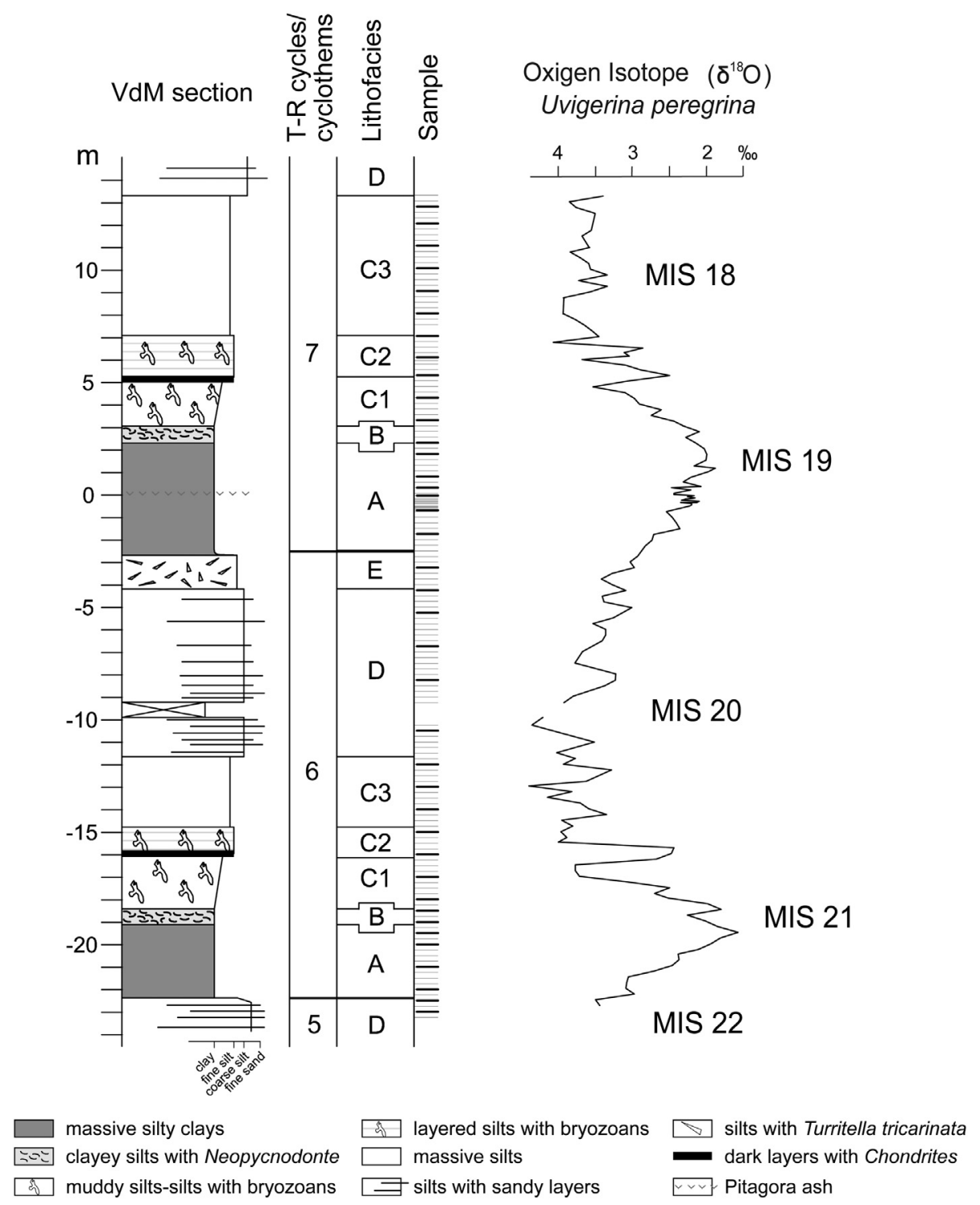

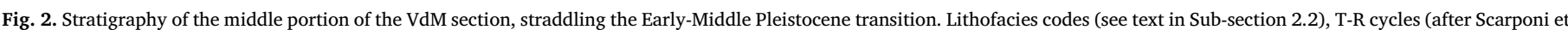

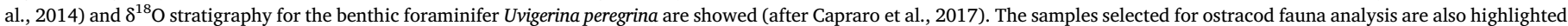
by a thick horizontal bar. MIS: Marine Isotope Stage.

basin, possibly occurred in the Middle Pleistocene (Capraro et al., 2011; Fig. 1B).

Hence, the San Mauro sub basin is represented by a synsedimentary growth syncline that developed since the late Calabrian (Rio et al., 1996; Massari et al., 1999), where continuous creation of accommodation space allowed the deposition of a cyclothemic, shallowing upward marine to continental succession, and the Valle di Manche section represents one of the best preserved locations (Fig. 1B).

\subsection{The Valle di Manche section}

The investigated portion of the Valle di Manche (VdM) section straddles the Early Middle Pleistocene transition (MIS 21 to early MIS 18 ) and is ca. $35 \mathrm{~m}$ thick. Bio, magnetostratigraphic proxies and $\delta^{18} \mathrm{O}$ records invariably constrain the VdM muddy deposits to the interglacial periods (MIS 21 and MIS 19 in Fig. 2), whereas the coarser grained successions developed under glacial (MIS 20 and MIS 18) conditions (Figs. 1B, 2). A prominent ash layer ("Pitagora Ash"), which approximates the Matuyama Brunhes geomagnetic reversal (mid MIS 19), is recorded within the upper portion of VdM section (Figs. 1B, 2; Capraro et al., 2017). The sequence stratigraphic framework of VdM section can be roughly outlined on the basis of the sole sedimentary features and contains two depositional units (cyclothems 6 and 7 in Massari et al., 2002; Figs. 1B, 2) interpreted as two transgressive regressive (T R) cycles (Capraro et al., 2017 and references therein). Indeed, each de positional cycle is composed of several lithofacies (Fig. 2), here briefly described (further details are available in Massari et al., 2007 and Capraro et al., 2017).

Lithofacies A up to $4.5 \mathrm{~m}$ thick, is represented by dark, massive muds (mainly silty clays) that contain in the lower portion large dispersed burrows, vegetal remains and sulphide nodules. The macrofossils are very scarce but increase upwards, and are mainly represented by assemblages dominated by Corbula gibba.

Lithofacies B $<1 \mathrm{~m}$ thick, is composed of loosely packed macrofossil remains embedded in a matrix of mud (clayey silts). Clumps of the gregarious deep sea ostreid Neopycnodonte along with unsorted, variable preserved shelly material are the most striking features of this lithofacies.

Lithofacies $\mathrm{C}$ several meters thick, is mainly represented by fine to coarse silts grouping a series of macrofossil rich units. It has been 
subdivided in three sub lithofacies based on macrofossil remains and lithologic features (Capraro et al., 2017). C1: ca. $2.5 \mathrm{~m}$ thick, is composed of amalgamated clayey silts rich in bryozoans and others un sorted macrofossils (mainly small sized mollusks). C2: up to 1.5 $\mathrm{m}$ thick, consists of silts rich in bryozoans alternating to poorly fossili ferous clayey strata characterized by Chondrites (disaerobic fossil traces, Bromley and Ekdale, 1984). C3: up to $6 \mathrm{~m}$ thick, massive silts con taining dispersed skeletal material (mainly mollusks and bryozoans), sparse vegetal remains and strings of the polychaeta Ditrupa that in crease in abundance upwards.

Lithofacies D is made up of meters thick successions of silts with sparse macrofaunal content, embedding $\mathrm{cm}$ to $\mathrm{dm}$ thick sharp based, densely laminated fine sands with abundant strings of plant debris. Coarser layers are locally interbedded with physical concentrations of disarticulated and oriented shells (mainly pectinids and polychaetes).

Lithofacies $\mathrm{E}$ is ca. $1 \mathrm{~m}$ thick of loosely packed shells of the semiinfaunal filter feeder Turritella tricarinata, within a silt matrix, retrieved only in the middle portion of the investigated section.

\section{Material and methods}

\subsection{Ostracod data collection}

Recently, a high resolution sampling campaign (ca. $20 \mathrm{~cm} / \mathrm{sample}$ ) has been performed for fossil and geochemical analyses taking the 'Pitagora Ash' as the reference zero level (Capraro et al., 2015; Fig. 2). Following stratigraphic criteria, 39 samples have been chosen to undertake a high resolution study of the ostracod fauna across the VdM section and within each depositional sequence. Selected samples are $1 \mathrm{~m}$ or less spaced apart from each other (Fig. 2). Special attention (higher sampling resolution) is paid to the muddy and silty units (li thofacies A C, E; Fig. 2), where a rich ostracod fauna is expected, while the sampling density becomes lower within sandy deposits (lithofacies D). The topmost sandy interval has been not analyzed (Fig. 2).

Samples (ca. $5055 \mathrm{~g}$ dry weight each) were soaked overnight in hydrogen peroxide solution $\left(4 \% \mathrm{H}_{2} \mathrm{O}_{2}\right)$, gently water screened with a 63 $\mu \mathrm{m}$ mesh sieve and dried in an oven at $40{ }^{\circ} \mathrm{C}$ for $8 \mathrm{~h}$. Each sample residue was qualitatively observed under a binocular microscope, de scribed and split into small portions. If possible at least 100150 well preserved ostracod valves were counted for each sample in the size fraction $>125$ $\mu \mathrm{m}$ (carapace was counted as two valves), otherwise all valves retrieved were counted. The presence of juveniles/young instars was noted, being a useful indicator of the autochthony along with the state of preservation of valves (Boomer and Eisenhauer, 2002), but not considered for counting. Ostracod specimens were mostly identified and counted at species level under a binocular microscope. Species/taxa relative abundances (\%) were also calculated for each sample, as well as the species diversity (fisher alpha index on samples with $n>10$ valves; Bassetti et al., 2010).

The VdM dataset includes $\sim 3650$ valves, belonging to ca. 90 species, 38 genera and 3 groups (Krithe spp., Parakrithe spp. and Callistocythere spp.). Fossil counts and relevant literature used for taxonomic identification are reported in Azzarone et al. (submitted) and Supplementary Material (SOM Table S1), respectively. Less than $10 \%$ of the encountered species are considered extinct. Furthermore, variable amounts of clearly allochthonous specimens, showing evi dences of transport (i.e., blackish colors, traces of abrasion and/or shell damages), are found. All the allochthonous specimens (mainly be longing to genera Aurila; Callistocythere; Carinocythereis; Costa; Lox oconcha; Limnocythere; Pontocythere; Pseudocandona; Urocythereis; Semicytherura; Krithe and Henryhowella) were not inserted in the VdM ostracod dataset.

The relative abundances of a selection of taxa (i.e. the most common and/or informative in terms of paleoenvironments) were stratigraphically plotted against the studied section. The structure and composition of this representative portion of the ostracod fauna were described and interpreted with respect to each lithofacies (Sub section 2.2 ), to define ostracod lithofacies relationship and possibly refine facies paleonvironmental characterization. The taxon relative abundance vs. stratigraphic depth includes a total of 4 groups and 14 species one of which, i.e. Cimbaurila cimbaeformis, is considered extinct in the Calabrian (Faranda and Gliozzi, 2008). Groups include species belonging to the same genus and sharing common ecological features.

\subsection{Gradient analysis}

Multivariate ordination techniques are applied to investigate ostracod faunal turnover and main controlling driver(s) in shelf depositional settings at the Early Middle Pleistocene transition. Specifically, Detrended Correspondence Analysis (DCA) and non Metric MultiDimensional Scaling (nMDS) are both used. These unconstrained posteriori ordination approaches are commonly employed with compositional data to identify major gradients in faunal composition (e.g., Scarponi and Kowalewski, 2004; Dominici et al., 2008; Gliozzi and Grossi, 2008; Ligios et al., 2008; Pascual et al., 2008; Ritter and Erthal, 2013; Belanger and Garcia, 2014; Kowalewski et al., 2015; Laut et al., 2016; Scarponi et al., 2017). Here, only DCA results are reported (nMDS outputs in Azzarone et al., submitted). Despite DCA multiple drawbacks (e.g., Beals, 1984; Jackson and Somers, 1991; McCune et al., 2002) and difficulties in interpreting higher order gradients (axis $>1$; Bush and Brame, 2010), DCA has proved to be effective when distribution of taxa relates to strong variations in controlling environmental variables (e.g., Wittmer et al., 2014), which is likely the case here at least for mollusk samples previously investigated (Scarponi et al., 2014).

For ordination analyses, the species level data matrix includes only samples showing $>20$ specimens ( 34 samples) and species recorded in more than one sample (51 species). As for DCA, faunal counts were log transformed to prevent most abundant species dominating the gradient. Whereas, nMDS analysis is performed on Bray Curtis distance on a set of culled matrices (Azzarone et al., submitted). However, varying the taxon and sample thresholds in both ordinations yielded comparable results (Fig. 2A F and Table 1A in Azzarone et al., submitted).

In addition, DCA and nMDS inferred ostracod faunal turnover was compared with that derived by DCA analyses of mollusk assemblages (see Scarponi et al., 2014) sampled from the same record by means of linear correlation (DCA mollusk vs. ostracod DCA/nMDS axis 1 sample scores; Table 1B in Azzarone et al., submitted). To avoid that environmental variables driving changes in molluscan and ostracod faunas could reflect mainly differences in the number of samples and their sampling resolution (i.e., samples 17 vs. 34 and average sampling resolution 2.2 vs. $1 \mathrm{~m} / \mathrm{sample}$, respectively), a reduced ostracod dataset comparable to the mollusk one (in sample size and sampling resolution), was compiled and DCA and nMDS run (results reported in Azzarone et al., submitted). Then, the ordination axis 1 ostracod sample scores were correlated with the mollusk derived DCA axis 1 output of Scarponi et al. (2014; Table 1B in Azzarone et al., submitted). It is important to note that both mollusk and ostracod derived DCA scores are based on samples taken in the same stratigraphic interval (average offset $0.2 \mathrm{~m}$, Table 1A in Azzarone et al., submitted).

As substrate consistency is one of the main drivers of ostracod turnover (and also could be related to water depth changes), we also employed a correlation model to evaluate if grain size (\% of sand in a sample) is a linear function of DCA sample scores (see Table $2 \mathrm{~A}$ in Azzarone et al., submitted).

\subsection{Environmental interpretation of the ostracod data}

The ostracod environmental characterization of VdM lithofacies, and an approximate interpretation of the main driver(s) of faunal turnover along the section (DCA axis 1), relied upon the auto ecological characteristics and the present day spatial distribution patterns of marine ostracods in the Mediterranean Sea and North Atlantic areas 
(e.g., Bonaduce et al., 1975; Breman, 1975; Athersuch et al., 1989; Sciuto and Rosso, 2008; Angue Mint'oo et al., 2013; Cabral and Loureiro, 2013; Frezza and Di Bella, 2015; Sciuto et al., 2015).

All the extant retrieved species have, to a good approximation, well to fairly known ecological features. However, the relationship existing between abundances of extant ostracod species and the major abiotic marine parameters, such as bathymetry, substrate granulometry, percentage of organic matter and dissolved oxygen, is far to be quantified or, especially for extinct species, poorly investigated. For the latter species (e.g., A. cimbaeformis, Cytherella gibba and Cytherella robusta among the most common in the VdM dataset) only indirect ecological inferences can be employed (Aiello et al., 2015). Hence, further paleoenvironmental information were provided by comparing our data with those recorded within other Mediterranean shelf successions of late Quaternary age (Barra, 1991; Faranda et al., 2007; Aiello et al., 2012, 2015; Sciuto and Meli, 2015) and those obtained from macro benthic samples previously collected along VdM section (Scarponi et al., 2014).

\section{Results}

\subsection{The ostracod content of VdM lithofacies}

The structure and composition of the autochthonous ostracod fauna are here analyzed for the first time and framed in the context of the lithostratigraphic framework recently defined by Capraro et al. (2017; Figs. 2, 4). Recurring vertical stacking patterns of lithofacies (except for facies E), developed during consecutive interglacial glacial periods (e.g., MIS 2120 and MIS 1918 in Fig. 2), are a characteristic trait of VdM section.

For each of the retrieved lithofacies (see Sub section 2.2), a description of the most representative/abundant ostracod taxa is reported below along with the paleoenvironmental interpretation. Selected species are also illustrated (see Fig. 3).

\subsubsection{Lithofacies $A$}

Within this lithofacies (ca. -22.5 to $-19 \mathrm{~m}$ and -2.5 to $2.25 \mathrm{~m}$; Fig. 4) the ostracod fauna is variable in terms of species richness and abundance, reaching a minimum close to the tephra layer ( $<10$ valves). Henryhowella sarsii, Krithe group and Cytheropteron species, mainly $C$. monoceros and $C$. ruggierii, are the dominant taxa with abundances up to $>30 \%$. Highly variable percentages of Palmoconcha subrugosa (0 20\%), Bosquetina tarentina (0 25\%) occur. Rare and scat tered valves of Paracytherois mediterranea, Bairdia conformis and Cy therella vulgatella $(<$ $10 \%)$ are also recorded. High percentages of Ar gilloecia group or Pterygocythereis coronata (up to ca. 20\%) occur within the middle upper portion of the lithofacies of both 6 and $7 \mathrm{~T}$ R cycles. Taxa presently recorded in infralittoral environments are scarcely re presented, except at the basal portion of both cycles where not negli gible percentages (up to $14 \%$ ) of Aurila convexa, Semicytherura ruggierii, Leptocythere multipunctata and Callistocythere species are recorded.

The occurrence of lower circalittoral epibathyal species (e.g., H. sarsii, $C$. monoceros, B. tarentina, $P$. coronata, Fig. 3), exclusively re corded at water depths $>6070 \mathrm{~m}$ in the Adriatic Sea (Bonaduce et al., 1975), indicates a bathymetry compatible with an outer shelf (e.g., between ca. $80150 \mathrm{~m}$ ). Variable amounts of $H$. sarsii, a species pre ferring abundant and newly produced food resources (Fig. 3; Sciuto and Rosso, 2008), reflect changeable conditions of food quality and avail ability. In particular, $H$. sarsii seems to be locally replaced by species of the opportunistic genus Cytheropteron that is able to tolerate elevated fluxes of old organic matter (Sciuto and Rosso, 2008). Moreover, in the middle upper part, high values of the infaunal (Krithe)/epifaunal (H. sarsii + Cytheropteron) ratio concomitant with the occurrence or in crease in relative abundances of taxa tolerant to xenoxic conditions

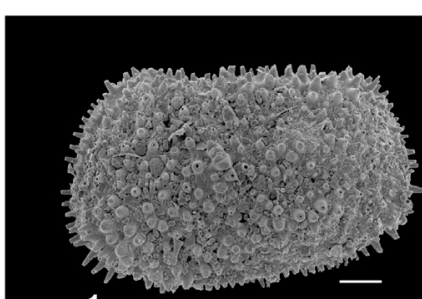

1
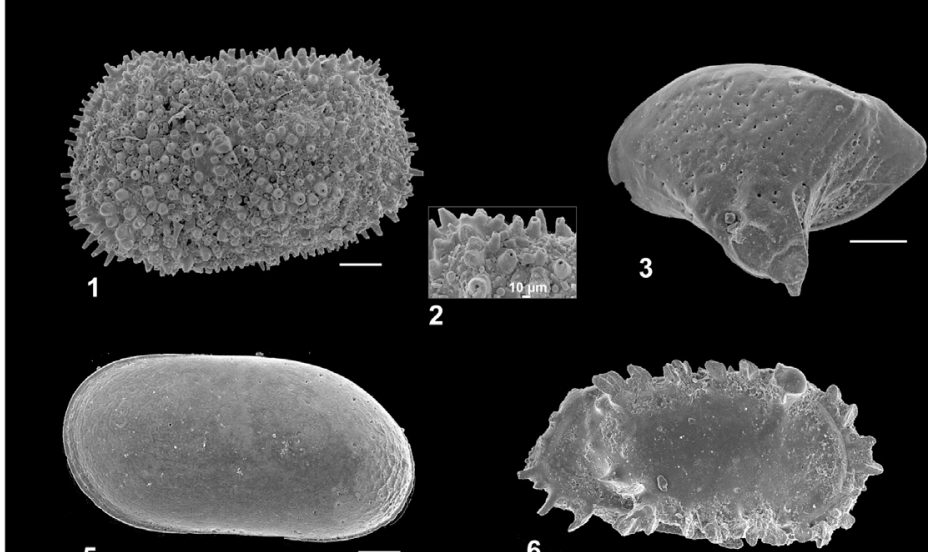

5

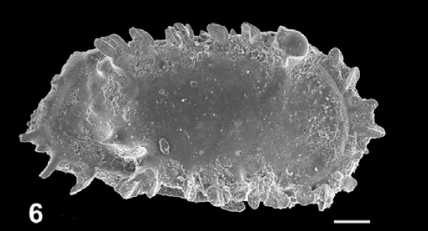

6

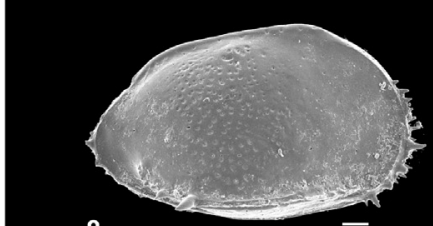

8

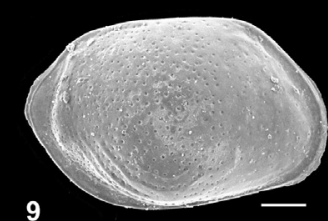

9

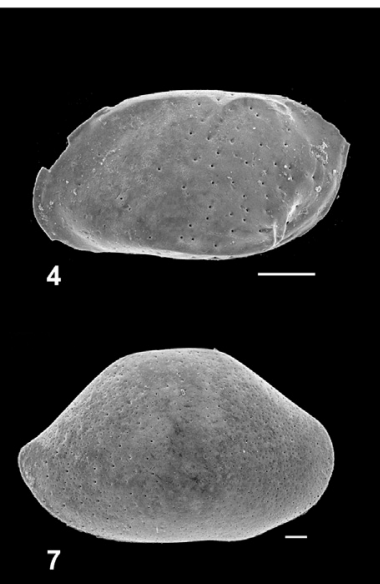

Fig. 3. Plate showing the SEM images of the key/most abundant ostracod species encountered within the VdM section. Scale bar $=100 \mu \mathrm{m}$. All lateral external views. Key: $\mathrm{RV}=$ right valve; $\mathrm{LV}=$ left valve. 1 Henryhowella sarsii (G.W. Muller, 1894); LV. 2: Close up of $H$. sarsii surface ornamentation (valve showed in 1). 3 Cytheropteron monoceros (Bonaduce et al., 1975); LV. 4: Cytheropteron ruggierii (Pucci 1955); LV. 5: Cytherella vulgatella (Aiello, Barra, Bonaduce \& Russo, 1996); LV. 6 : Pterygocythereis coronata (Roemer, 1838); RV. 7: Bairdia conformis (Terquem, 1878); RV. 8: Bosquetina tarentina (Baird, 1850); RV. 9: Palmoconcha subrugosa (Ruggieri 1967); RV. 10: Sagmocythere versicolor (G.W. Muller, 1894); LV. 11: Leptocythere multipunctata (Seguenza 1883); LV. 12 Semicytherura ruggierii (Pucci, 1955); RV. 13: Aurila convexa (Baird, 1850); RV. 


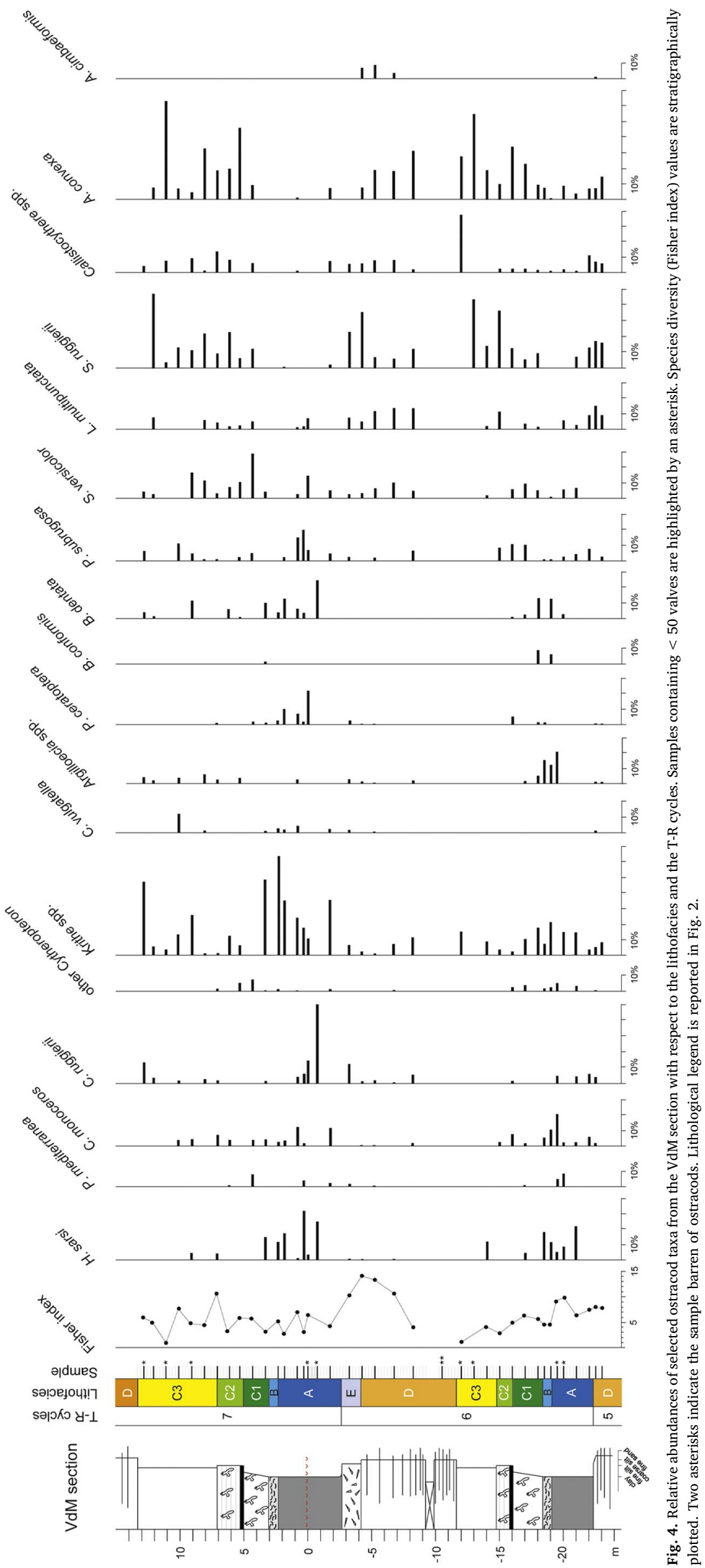


(i.e., Argilloecia group or C. vulgatella; Fig. 3), suggest lower levels of oxygenation (Whatley, 1990; Aiello et al., 2015). In contrast, the remarkable amounts of infralittoral/upper circalittoral taxa (i.e., A. convexa, Callistocythere spp., L. multipunctata; Fig. 3) recorded in the low ermost portion of lithofacies A are interpreted to reflect a gradual increase in water depth.

\subsubsection{Lithofacies $B$}

The thin lithofacies B (ca. -19 to $-18.5 \mathrm{~m}$ and 2.25 to $3 \mathrm{~m}$; Fig. 4) shows a low diversified ostracod fauna dominated by Krithe group (ca. 7 64\%) and $H$. sarsii (ca. $1218 \%$ ), accompanied by lower amounts of $B$. tarentina (up to ca. $12 \%$ ) and C. monoceros $(<10 \%)$. Notable percentages of Argilloecia species (ca. 15\%) and B. conformis (up to 10\%) are found only within the lower T R cycle (cycle 6). Rare valve of $P$. coronata (< $3 \%$ ) also occur. Taxa commonly reported from the infra littoral/upper circalittoral settings (i.e., Aurila, Callistocythere and Lep- tocythere species) are almost absent, except for the sporadic occurrence of $A$. convexa (abundances $07 \%$ ).

The dominance of species preferring water depths $>60 \mathrm{~m}(H$. sarsii, C. monoceros, B. tarentina, B. conformis; Fig. 3), and the absence or low percentages of infralittoral/upper circalittoral genera indicate de position in an outer shelf environment. Despite the good preservation state of A. convexa shells, the local occurrence of this infralittoral upper circalittoral species can be related to sea bottom currents displacing ostracods from shallower water depths.

\subsubsection{Lithofacies $C 1$}

Within this lithofacies (ca. -18.5 to $-16 \mathrm{~m}$ and 3 to $5 \mathrm{~m}$; Fig. 4) the ostracod fauna is quite diversified and shows the occurrence of lower circalittoral epibathyal taxa (i.e., H. sarsii, C. monoceros, B. tarentina, B. conformis and Argilloecia species), mainly concentrated in correspondence of the lower portion of this unit. However, species preferring infralittoral upper circalittoral settings (i.e., A. convexa, S. ruggierii and Leptocythere multipunctata; Fig. 3), here constitute a remarkable com ponent of the ostracod fauna. In particular, these species show in both $\mathrm{T}$ R cycles an upward increasing trend paralleled by a strong decrease in relative abundances of Krithe group. Palmoconcha subrugosa and S. ruggierii occur as secondary taxa $(<13 \%)$, while minor amounts of Callistocythere spp. (0 6.4\%) are found.

The composition of the ostracod fauna points to an upper circa littoral setting, as a mid shelf (ca. $5080 \mathrm{~m}$ water depth range), with a granular cohesive (silt clay) bottom according to the high amounts of species preferring mixed substrates (A. convexa, S. versicolor in Fig. 3 , and $S$. ruggierii). The upward increase trend in infralittoral upper cir- calittoral species, which progressively replaces Krithe group as domi- nant taxa, is interpreted to reflect a decrease in paleobathymetry and, possibly, a concomitant increase in vegetation cover at the sea floor.

\subsubsection{Lithofacies $C 2$}

Lithofacies C2 (ca. -16 to $-15 \mathrm{~m}$ and 5 to $7 \mathrm{~m}$; Fig. 4) shows an ostracod fauna dominated by $S$. ruggierii (ca. $9.837 \%$ ) and A. convexa (ca. $9.820 \%$ ), with the secondary occurrence of L. multipunctata (ca. 2 $11.7 \%$ ), Callistocythere (ca. $314 \%$ ) and Krithe (ca. $1.712 .7 \%$ ) groups, and C. monoceros (3 7.5\%). Variable percentages of B. tarentina $(06.4 \%)$, P. subrugosa (0 8.8\%) and S. versicolor (0 7.4\%) are also found.

The dominance of species typical of upper circalittoral infralittoral environments (i.e., S. ruggierii, A. convexa, L. multipunctata and Callistocythere spp.) along with the not negligible occurrence of taxa preferring water depths from the upper circalittoral zone downward (mainly C. monoceros and B. tarentina; Fig. 3) suggests a mid shelf depositional setting. High percentages of epiphytic taxa, mainly $A$. convexa and Callistocythere species, indicate a dense vegetation cover at the bottom.

\subsubsection{Lithofacies C3}

Along this lithofacies (ca. -15 to $-11.5 \mathrm{~m}$ and 7 to $13.5 \mathrm{~m}$; Fig. 4) ostracods are generally scarce $(<10$ valves) and characterized by a variable species diversity. Aurila convexa, S. ruggierii and Callistocythere spp. are well represented, with the secondary occurrence of Krithe group that locally peaks (up to ca. 48\%) within the $\mathrm{T}$ R cycle 7 , in concomitance of a slight increase of B. tarentina, $H$. sarsii and/or $C y$ theropteron species (relative abundances $>4 \%$ ). Generally, scattered valves of $P$. subrugosa, $C$. vulgatella and Argilloecia species occur in the investigated interval, reaching in one sample from the uppermost portion a total amount of ca. 38\% (T R cycle 7; Fig. 4).

The dominance of $S$. ruggierii and epiphytic taxa as $A$. convexa and Callistocythere spp., along with the secondary occurrence of ostracods commonly recorded at water depths $>6070 \mathrm{~m}$ (above all the Krithe group; Bonaduce et al., 1975), points to a vegetated mid shelf setting. However, the low abundance values and the highly variable species diversity of the ostracod fauna suggest unstable environmental conditions. Specifically, the high frequency turnover involving A. con vexa + $S$. ruggierii and Krithe group + other circalittoral bathyal species (mainly $B$. tarentina), recorded within the uppermost $\mathrm{T}$ R cycle, possibly reflects abrupt shifts in water depths sometimes paralleled by changes in bottom conditions. In this regard, the temporary establishment of a more pelitic substrate and lower levels of oxygenation is locally tracked by the high amounts of the opportunistic species P. subrugosa (Fig. 3), that prefers muddy substrate, and taxa tolerant to xenoxic conditions (C. vulgatella and Argilloecia group).

\subsubsection{Lithofacies $D$}

This lithofacies (ca. -24 to $-22.5 \mathrm{~m} ;-11.5$ to $-4 \mathrm{~m}$ and 13 to 15 ; Fig. 4) commonly contains a rich ostracod fauna showing a marked upward increase in abundance (from $\sim 20$ to $\sim 100$ valves) and species richness. The ostracod fauna is almost exclusively composed of typical infralittoral upper circalittoral genera (i.e., Aurila, Callistocythere, Semicytherura and Leptocythere) with the dominance of Aurila Cim baurila species (up to $33 \%$ ), mainly represented by $A$. convexa and $C$. cimbaeformis. The latter is an extinct species (Early Pliocene Calabrian; Faranda and Gliozzi, 2008). Within the $\mathrm{T}$ R cycle 6, Leptocythere multipunctata displays an upward decreasing trend. A similar trend is also showed by $P$. subrugosa, $C$. ruggierii and Krithe group that are en countered with low percentages (commonly $<8 \%$ ). Rare displaced valves of freshwater low brackish ostracods belonging to genera Lim nocythere and Pseudocandona are locally found.

The ostracod fauna structure (high species diversity) and composition (i.e., dominance of infralittoral species along with absence/scarcity of species typical of lower circalittoral or deeper water species) indicate an inner mid shelf environment with silty sandy bottoms covered by vegetation. The upward decreasing trend of opportunistic taxa preferring muddy substrates (mainly $L$. multipunctata, $P$. subrugosa and Krithe group) reasonably reflects the progressive establishment of coarser bottoms and shallower and more stable environmental conditions according to the increase in species diversity. The local occurrence of few freshwater low brackish ostracods fits with a shallow marine environment occasionally influenced by river fluxes.

\subsubsection{Lithofacies $E$}

Only one sample was analyzed for this lithofacies $(-4$ to $-2.5 \mathrm{~m}$; Fig. 4). It contains an ostracod fauna characterized by high amounts of $S$. ruggierii (ca. $23.5 \%$ ) and C. ruggierii (ca. $12.5 \%$ ), that is the only Cytheropteron species found. Callistocythere and Krithe groups occur with percentages $<10 \%$. Rare to very rare valves of $C$. vulgatella, $P$. cor onata, S. versicolor, P. subrugosa, P. mediterranea, H. sarsii and Argilloecia spp. are also found. Aurila species are not recorded.

The occurrence of one species of Cytheropteron (C. ruggierii; Fig. 3), the only not rare in the Mediterranean infralittoral zone (Bonaduce et al., 1975; Aiello et al., 2015), and the very low amounts of taxa presently recorded at water depths deeper than $6070 \mathrm{~m}$ (i.e., $\mathrm{H}$. sarsii 


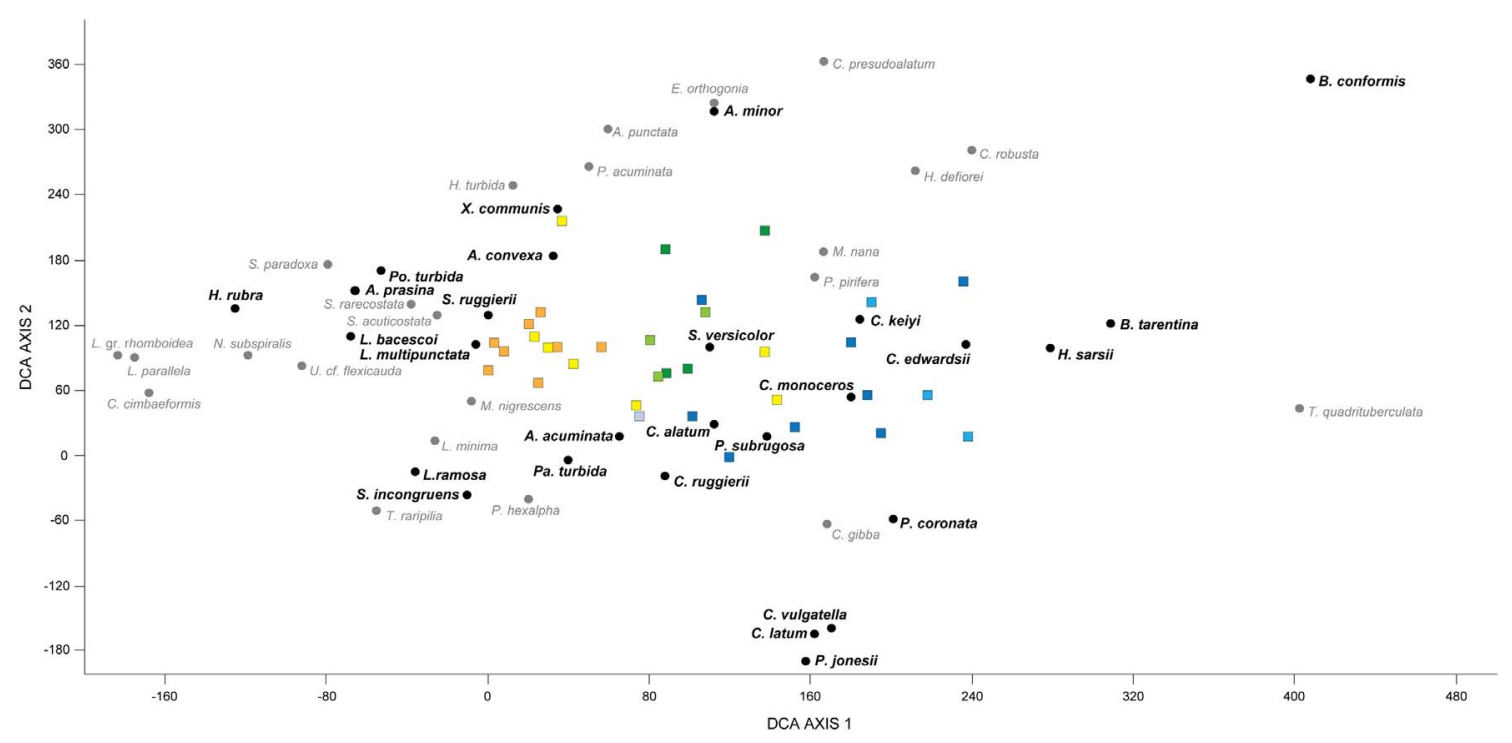

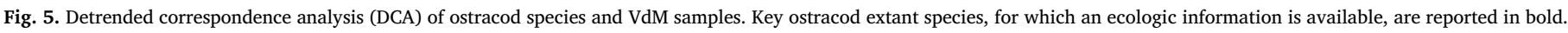

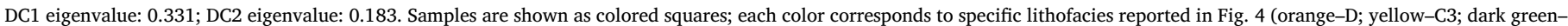
$\mathrm{C} 2$; light green-C1; light blue-B and dark blue-A). (For interpretation of the references to color in this figure legend, the reader is referred to the web version of this article.)

and Argilloecia spp.; Bonaduce et al., 1975) point to a depositional setting compatible with the upper (?) mid shelf.

\subsection{Indirect gradient analysis of VdM ostracod fauna}

The application of DCA (and nMDS) to the VdM ostracod dataset (34 samples and 51 species; Azzarone et al., submitted), reveals a continuous distribution of both species and samples along the major axis of variation (DCA 1 Fig. 5; Fig. 1 and Table 1A in Azzarone et al., submitted). The effective occurrence of a strong environmental gradient underlying the major axis of variation is strengthened by the fact that both nMDS and DCA ordinations returned comparable results, while varying the taxon and sample thresholds (Fig. 2 in Azzarone et al., submitted). In contrast, DCA axis 2 (DC2) is not easily interpretable as no evident relationship with any discernible physical chemical variable related to ostracod ecology has been recognized.

The faunal turnover expressed along the major axis of variation (i.e., DCA1) can be associated with bathymetry, a complex gradient commonly retained to drive macrofaunal turnover in Quaternary or older marine successions (e.g., Scarponi and Kowalewski, 2007; Ayoub Hannaa et al., 2013; Tyler and Kowalewski, 2014; Danise and Holland, 2017). Indeed, the position of several key ostracod extant species (highlighted in Fig. 5 and illustrated in Fig. 3), follows a positive bathymetric gradient from the left (DC1 low scores) to the right (DC1 high scores) side of the axis of major variation. In particular, species typically found in infralittoral environments (e.g., Aurila prasina; Hil termannicythere rubra) and infralittoral upper circalittoral species reaching their highest abundances at water depths $<5070 \mathrm{~m}$ (e.g., Aurila convexa; Pontocythere turbida; Leptocythere bacescoi; Leptocythere multipunctata; Leptocythere ramosa; Semicytherura incongruens) plot on the left extremity of DC1 (DC1 < 50). Deep sea species (lower circa littoral epibathyal; > $100 \mathrm{~m}$ depth) e.g., Henryhowella sarsii; Bosquetina tarentina; Baidia conformis assemble on the far right side (DC1 > 240). Whereas, in the middle DC1 portion (between 140 and 240), circa littoral taxa occur. Only two species presently abundant in shallow waters (i.e., Microxestoleberis nana and Hemicytherura defiorei in Fig. 5) attain high DC1 scores (deeper environments). This mismatch between present day preferred bathymetry and DC1 scores of these two scattered species possibly indicates reworking in deeper setting. The VdM samples also distribute along DC1 to the lithofacies sup posed position along an onshore offshore gradient (Fig. 5). Samples collected from the silt sandy silt lithofacies D and C3 cluster (orange and yellow squares in Fig. 5) mainly locate on the left side (lower DC1 values). Moving toward higher DC1 values, samples collected from the fossil rich shelf lithofacies (e.g., C1 and C2 showed in Fig. 5 as dark and light green squares, respectively) firstly occur followed by samples belonging to the deep sea muddy lithofacies (A and B; dark and light blue squares in Fig. 5). However, the weak linear correlation $(r=$ $-0.29 p=0.09$ ) between sample granulometry and DCA1 sample score (Table 2C in Azzarone et al., submitted) suggest that substrate is not a strong driving factor of ostracod turnover along VdM section at this spatial and temporal scale of observation.

\section{Discussion}

5.1. Common causative factors drive ostracod and mollusk faunal turnover along the VdM section

The availability of both meiofaunal and macrofaunal censuses from the same lithofacies of the VdM succession offers the greatest potential for evaluating if such widely used biological proxy respond in a comparable manner to environmental drivers during two consecutive interglacial glacial cycles (i.e. MIS 21 MIS 20 and MIS 19 MIS 18).

The tight linear correlation between the first DCA axis 1 sample score of mollusk (from Scarponi et al., 2014) and DCA 1 ostracod da taset (r2 $=0.80, p<0.001$ ) indicates a strong relationship between the faunal turnover of the two investigated ecological groups along the VdM succession. Similarly, this correlation holds also when the os tracod dataset is culled to be more similar, in terms of sample size and sample spacing, to the molluscan one ( $\mathrm{r} 2=0.78, \mathrm{p}<0.001)$ and also when nMDS technique is employed (see Azzarone et al., submitted). Hence, correlation analyses of meio and macrofaunal censuses support the hypothesis that much of the variation in community composition (faunal turnover) recorded across the VdM lithofacies, which cover a wide spectrum of shelf depositional settings (Figs. 2, 4; Section 4), is tied to a common causative factor.

Recently published studies focused on the estimation of differences in the environmental drivers for ostracods vs. foraminifers (Yasuhara et al., 2012) and mollusks vs. foraminifers (Belanger and Garcia, 2014) in marine depositional settings. Quantitative inferences obtained in these studies suggested that foraminifers are sensitive to different environmental conditions compared to the other groups, reinforcing the 
supposition that both mollusk and ostracod faunas could be associable to the same drivers of community composition, especially when ana lyzed along a substantial portion of the marine gradient (i.e., entire shelf). However, to our knowledge, our reconstruction at VdM is one of the few studies specifically dealing with macro and meiofaunal re sponse to environmental drivers in open marine settings.

This redundancy should not be viewed as unfavorable to integrated analyses of ostracods and mollusks. On the contrary, the VdM results strengthen the high value of these faunal groups as paleoenvironmental tools, which may substitute each other or/and balance each other's weaknesses, especially considering that paleobiological data are strongly influenced by the stratigraphic framework. Indeed, the distribution of taxa along sedimentary successions is controlled not only by ecological processes (e.g., taxa environmental niches), but also (and equally important) by the sedimentary processes that govern whether fossil containing sediments are deposited and preserved (Patzkowsky and Holland, 2012).

\subsection{Drivers of macro and meiofaunal composition}

The joint consideration of macro and meiofaunal associations from the VdM section highlighted a common cause driving faunal turnover along the section. Furthermore, the available ecological information on ostracods coupled with the already investigated molluscan main drivers of faunal turnover, explored in a companion paper (Scarponi et al., 2014), suggest that most of environmental variation could be attributed to bathymetry (Fig. 5 and Section 4.2), and correlated environmental parameters (see also Fig. 3 in Azzarone et al., submitted).

In marine depositional contexts, bathymetry is a well known indirect driver of macrofaunal turnover (e.g., Tyler and Kowalewski, 2014) and in the fossil record bathymetry commonly shows the highest correlation with faunal turnover (Patzkowsky and Holland, 2012; Wittmer et al., 2014; Scarponi et al., 2017). This is especially evident when, as in this case, the sedimentary succession records glacial/in terglacial cycles developed along the entire shelf (Rio et al., 1996; Capraro et al., 2017). Concerning ostracods, a strong influence of bathymetric variations linked to glacio eustatic phases has been clearly documented from the Montalbano Jonico shallow marine $(<200 \mathrm{~m}$ of inferred water depth) section (Aiello et al., 2015).

On the other hand, the assessment and evaluation of the relative weights of the environmental variables linked to the shelf bathymetric gradient, and potentially driving biotic response to environmental change should require a wide set of measurements not yet available. Nevertheless, such highly interrelated variations are here hinted by ecology information of ostracod taxa (Figs. 4, 6).

Given the coarse bathymetric information on ostracods taxa here recovered, water depth calibrations of unconstrained ordinations of ostracod samples (DCA1) rely on the rich amount of quantitative in formation on bathymetry preference available for the majority of the mollusk species retrieved in concomitance or proximity of sampled horizons. Given the non perfect concordance between the two sets of sampling schemes (i.e mollusks vs. ostracods), reduced major axis regression of mollusk derived bathymetric estimates of samples vs. ostracods DCA 1 sample scores, allowed a rough calibration of bathymetric ostracod samples and, more importantly, derived trends along the section (Fig. 6; Azzarone et al., submitted).

\subsection{Paleoenvironmental and sequence stratigraphic implications of the VdM faunal patterns}

The ostracod mollusk faunal turnover recorded by DC1 sample scores (Fig. 6) outlines two similar $\mathrm{v}$ shaped patterns of variation that reflects two increasing decreasing trends in water depth. The latter mimic very closely the glacial interglacial $\delta^{18} \mathrm{O}$ cycles that have been interpreted as correlative to the MIS 21 MIS 20 and MIS 19 MIS 18 intervals, respectively (Fig. 6; Capraro et al., 2005, 2017; Azzarone et al., submitted). For both cycles, the internal organization of facies is virtually identical, especially in the fine grained intervals (Fig. 2), confirming that the main traits of the VdM succession were primarily shaped by glacioeustasy (Rio et al., 1996). Nonetheless, superimposed is a strong local subsidence that, in spite of the massive sediment supply, promoted the continuous creation of accommodation space, thus ensuring the persistence of open marine conditions also in the course of eustatic sea level minima (Massari et al., 2007).

Ecology information on key taxa shows also how changes in substrate conditions (lithology, vegetation cover and oxygen/food type availability) are relatable to water depth inferences. Indeed, open marine ostracods preferring muddy substrates (i.e., $H$. sarsii, $C$. mono ceros and Paracytherois mediterranea) and species commonly recorded on vegetated sandy bottoms (i.e. Aurila and Callistocythere species) show, respectively, concordant and specular stratigraphic variation respect to DC1 sample score (Fig. 6; Azzarone et al., submitted). Thus, changes in substrate conditions (i.e. lithology and vegetation cover) tracked by the ostracod fauna are strictly connected to water depth inferences. In contrast, the temporary establishment of a stressed en vironment recorded by peaks in opportunistic species, tolerant to low oxygen levels (i.e. Palmoconcha subrugosa, Palmoconcha turbida, Cy therella vulgatella and Argilloecia group), appears less clearly predictable in respect to water depth variations.

In the lowermost portion of the VdM section (ca. $2419 \mathrm{~m}$ below the Pitagora Ash; Fig. 6), at the transition between lithofacies D A, the abrupt upward increase in DC1 scores is paralleled by a marked shift toward lighter oxygen isotopic ratio, testifying the occurrence of a distinct bathymetric change during the interglacial MIS 21 (Fig. 6). Specifically, within the $3 \mathrm{~m}$ thick interval of muddy deposits (litho facies A) the ostracod water depth estimates record a steady deepening (from ca. $60 \mathrm{~m}$ to ca. $120 \mathrm{~m}$; Fig. 6). The onset of this fast deepening upward trend, retrieved in proximity of decimetric thick sandy beds containing the boreal guest A. islandica (Scarponi et al., 2014), is re tained to represent the transgressive surface (TS) separating the forced regressive/ lowstand coarse deposits attributed to MIS 22 (estimated paleodepth ca. $50 \mathrm{~m}$ in the lower portion of the studied section, which possibly does not record the full glacial conditions but the following glacial termination; Fig. 6), from the overlying increasingly finer suc cession of MIS 21 (Fig. 6). The retrogradational stacking pattern of facies, commonly characterizing transgressive successions (TST in Fig. 6), is also highlighted by the dominance of deep sea ( $>70 \mathrm{~m}$ ) mud lover species, which depicts a coupled change in water depth and substrate lithology in respect to the underlying inner middle shelf set ting with vegetated coarser grained bottoms (lithofacies D; Section 4.1.6). Moreover, changeable conditions in terms of oxygen availability likely occur (lithofacies A; Section 4.1.1.) as testified by local peaks in opportunistic taxa and the mollusk Corbula gibba. The latter is here indicative of stressed conditions (see also Ceregato et al., 2007; Tomašovýtch et al., 2017).

Up section, the turnaround point of DC1 scores is recorded in correspondence of the Neopycnodonte unit (lithofacies B), where the max imum estimates of water depth are obtained (i.e. ca. $140 \mathrm{~m}$ ) slightly above the lightest oxygen isotopic ratios (Fig. 6). Thus, based on coupled macro and meiobenthic inferences, lithofacies B is considered an ecological condensed interval (see also Scarponi et al., 2014, 2017), representative of the maximum flooding zone (MFZ) developed during the MIS 21 interglacial peak (Fig. 6). Although no distinctive sedimentological features of the maximum flooding surface (MFS) can be identified within unit B, an evident seaward shift of facies is here highlighted by the initially gradual and then abrupt drop in DC1 scores recorded at the onset of the bryozoans rich silt deposits (lithofacies $\mathrm{C} 1$ ). The decreasing trend in DCA sample score reflects a rapid and continuous decrease in bathymetry (from ca. $120 \mathrm{~m}$ to ca. $30 \mathrm{~m}$; Fig. 6 , Azzarone et al., submitted) occurred during the glacial period MIS 20 . The upward increment of sparse vegetal remains and strings of the polychaeta Ditrupa, indicative of high sedimentation/turbidity and 


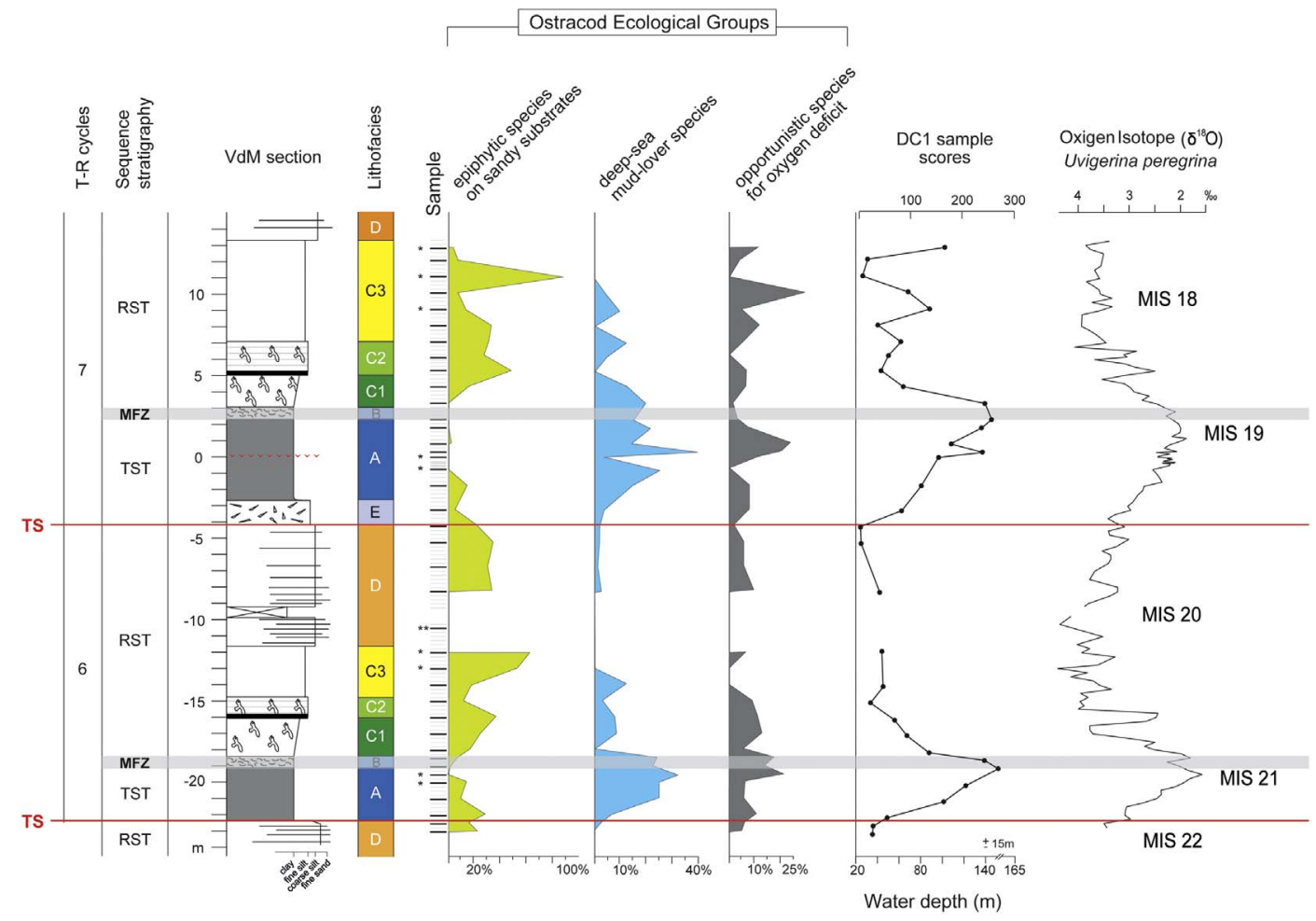

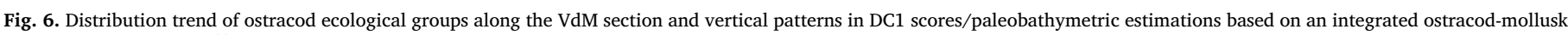

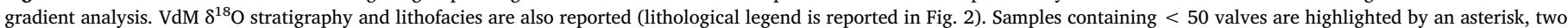

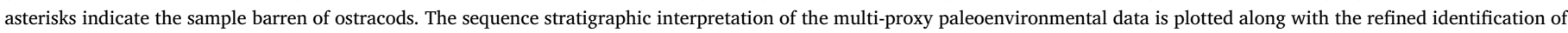
the T-R cycles. TST: transgressive system tract; RST: regressive systems tract; TS: transgressive surface and MFZ: maximum flooding zone, MIS: Marine Isotope Stage.

unstable mixed substrates along inner shelf (Cosentino and Giacobbe, 2006), and concomitant shift toward heavier values of $\delta^{18} \mathrm{O}$ (Fig. 6) support the interpretation. The re establishment of progressively shal lower inner shelf conditions during the MIS 20 sea level fall is clearly tracked also by the abrupt diffusion of epiphytic taxa preferring sandy substrates to the detriment of deep sea mud lover species (Fig. 6). According to the development of a shelf vegetated sandy bottom, opportunist species show an overall upward decreasing trend (Fig. 6).

Although the presence of a scarce ostracod fauna prevents a continuous record of DC1 scores across the overlying silty sandy deposits (lithofacies C3 and D), a relatively stable lowstand paleobathymetry can be identified during fully glacial conditions of MIS 20 (heaviest values of $\delta^{18} \mathrm{O}$ in Fig. 6). A minimum of water paleodepth is reached close to the upper boundary of lithofacies D (Fig. 6), where mud lover species are almost absent and concentrations of disarticulated and or iented shells are indicative of high energy events, such as river floods and/or storm induced flows within shelf settings (Massari et al., 1999).

The overlying finer deposits/lithofacies $\mathrm{E}$ is indicative of a deeper environment, subject to influence of riverine waters, as testified by high abundance of T. tricarinata (Dominici, 2001). This renewed sea level rise is accompanied by a slightly increase in deep sea species, paralleled by a sudden fall of epiphytic taxa (Fig. 6). This turnover in ostracod fauna composition is clearly revealed by an abrupt increase in DC1 score values and tracks a rapid water depth shift $(\sim 50 \mathrm{~m}$ to $\sim 80 \mathrm{~m}$ within 0.5 $\mathrm{m}$ of stratigraphic thickness), attributed to the MIS 19 transgression (upward lighter trend in oxygen isotopic ratios; Fig. 6). This rapid and steady deepening trend is responsible for the subsequent re establishment of an outer shelf environment with muddy substrates (high amounts of mud lover taxa) and changeable oxygen conditions suggested by peaks in opportunistic species in the middle portion of lithofacies A (Fig. 6). Hence, the lithofacies E lower boundary is marked by a shift from coarsening and shallowing upward trend (i.e., coupled litho and bio facies C1 D) to a fining and deepening upward succession (i.e., lithofacies E A; Fig. 6). This shift from shallowing to deepening trend is interpreted to mark the transgressive surface (TS linked to MIS 19 interglacial; Fig. 6).

Thus, with respect to previously defined sequence stratigraphic interpretation (Fig. 2; Scarponi et al., 2014), the transgressive surface separating sequence 6 to 7 , is here positioned at ca. $-4 \mathrm{~m}$ (Fig. 6), thanks to a higher resolution sampling scheme. As for the precedent depositional cycle attributed to MIS 21 MIS 20, ostracod fauna varia tions clearly trace an increasing decreasing bathymetric trend with the turnaround point recorded within the upper portion of the Neopycnodonte unit, containing the MFS (water depth estimate of ca. $140 \mathrm{~m}$ ), to the overlying bryozoans deposits (lithofacies C1 and C2). The latter are constrained to the glacial inception of MIS 18 by the increasing $\delta^{18} \mathrm{O}$ values (Fig. 6).

Integrated standard and ordination analyses of ostracod fauna also highlight the superposition of higher frequency changes on the overall shallowing upward trend recorded within the lithofacies C3 of MIS 18 (Fig. 6). One out of two main peaks in DC1 scores (at ca. $9 \mathrm{~m}$ and $13 \mathrm{~m}$ ) matches with an increase in deep sea mud lover species reinforcing the hypothesis of small scale deepening pulsations (in the range of tens meters). However, at this resolution scale, we cannot totally exclude the influence of other factors, as upwelling currents. Comparable conditions have been identified by ostracods within coeval (MIS 18) shelf deposits belonging to the Montalbano Jonico MJ section (Aiello et al., 2015), and interpreted as the consequence of upwelling episodes, leading to the sporadic co occurrence of "deep" and "shallow" auto chthonous ostracod taxa. The development of unstable paleoenviron mental conditions during the glacial MIS 18 is also supported by the local occurrence within lithofacies C3 of peaks in opportunistic taxa tolerant to oxygen deficit (Fig. 6). High amounts of these taxa ( $>1015 \%$ of relative abundance) also characterize some portions of the muddy intervals (lithofacies A and B), suggesting the sporadic oc currence of relatively low oxygen conditions during interglacial periods 
(i.e. MIS 21 and MIS 19; Fig. 6). Coeval kenoxic events have been re- cognized by Aiello et al. (2015) at the Montalbano Jonico section within intervals containing the deepest ostracod assemblages.

\section{Conclusions}

The combined use of a high resolution, multi proxy (ostracods and mollusks) dataset and multivariate ordination techniques (DCA and nMDS) on the VdM section (Calabria, Southern Italy) has proved to be a powerful tool for investigating the main controlling driver on meio and macro faunal turnover in past shelf settings. Pairwise, quantitative ostracod analyses have demonstrated to be able to identify, within a shelf succession deposited during two consecutive glacial interglacial cycles, specific stratal stacking patterns and a refined paleonvironmental and sequence stratigraphic interpretation of the section.

The major outcomes of this study can be summarized as follows:

- Ordination analysis performed on the VdM ostracod dataset shows a distinct environmental gradient underlying the faunal turnover. This complex gradient corresponds to bathymetry and associated parameters (e.g. vegetation cover), as documented by the ecological information available for key extant species. Ostracod and mollusk communities respond in a synchronized and similar manner to the environmental changes occurred on the shelf during two consecutive glacial interglacial cycles, from MIS 21 to 18.

- The integrated, multivariate analysis of ostracods and mollusks furnishes a high resolution, reliable estimation of the paleobathy metric trends recorded within the VdM section, allowing an improved differentiation between system tracts and identification of sequence stratigraphic surfaces. Respect to previous studies, here the two TSs which represent the cycle boundaries are precisely constrained by a high resolution sampling that depict two rapid increases in water depth values at the inception of interglacials MIS 21 and MIS 19 identified within the VdM section by benthic for aminifera $\delta^{18} \mathrm{O}$ values.

- The joint consideration of macro and meiofaunal associations proves to have the greatest potential for interpreting ancient shallow marine successions in a paleonvironmental sequence stratigraphic perspective, meanwhile examining the biological and sedimentary response of shelf settings to glacio eustatic oscillations.

Source Data along with any additional Extended Data display items

are available in Azzarone et al. (submitted). Supplementary data asso ciated with this article can be found in the online version, at https:// doi.org/10.1016/j.palaeo.2017.12.042.

\section{Acknowledgments}

This work was supported by the RFO 2016, University of Bologna, Italy (DS and VR). We are strongly indebted to two anonymous re viewers for their suggestions and comments to the paper. We are also grateful to Roberta Randi for the technical help with SEM images.

\section{References}

Aiello, G., Barra, D., Bonaduce, G., 2000. Systematics and biostratigraphy of the ostracoda of the Plio-Pleistocene Monte S. Nicola section (Gela, Sicily). Boll. Soc. Paleontol. Ital. 39 (1), 83-112.

Aiello, G., Barra, D., De Pippo, T., Donadio, C., 2012. Pleistocene Foraminiferida and Ostracoda from the Island of Procida (Bay of Naples, Italy). Boll. Soc. Paleontol. Ital. $51(1), 50$.

Aiello, G., Barra, D., Parisi, R., 2015. Lower-Middle Pleistocene ostracod assemblages from the Montalbano Jonico section (Basilicata, Southern Italy). Quat. Int. 383, 47-73.

Amorosi, A., Rossi, V., Scarponi, D., Vaiani, S.C., Ghosh, A., 2014a. Biosedimentary record of postglacial coastal dynamics: high-resolution sequence stratigraphy from the northern Tuscan coast (Italy). Boreas 43, 939-954.

Amorosi, A., Antonioli, F., Bertini, A., Marabini, S., Mastronuzzi, G., Montagna, P., Negri, A., Rossi, V., Scarponi, D., Taviani, M., Angeletti, L., Piva, A., Vai, G.B., 2014b. The
Middle-Upper Pleistocene Fronte section (Taranto, Italy): an exceptionally preserved marine record of the last interglacial. Glob. Planet. Chang. 119, 23-38.

Angue Minto'o, C.A., Bassetti, M.A., Morigi, C., Ducassou, E., Toucanne, S., Jouet, G., Mulder, T., 2015. Levantine intermediate water hydrodynamic and bottom water ventilation in the northern Tyrrhenian Sea over the past 56,000 years: new insights from benthic foraminifera and ostracods. Quat. Int. 357, 295-313.

Angue Mint'oo, C.A., Bassetti, M.A., Jouet, G., Toucanne, S., 2013. Distribution of modern ostracoda and benthic foraminifera from the Golo margin (East-Corsica). Rev. Paléobiol. 32 (2), 607-628.

Athersuch, J., Horne, D.J., Whittaker, J.E., 1989. Marine and brackish water ostracods (superfamilies Cypridacea and Cytheracea): keys and notes for the identification of the species. In: Brill Archive. Vol. 43.

Ávila, S.P., Ramalho, R.S., Habermann, J.M., Quartau, R., Kroh, A., Berning, B., Johnson, M., Kirby, M.X., Zanon, V., Titschack, J., Goss, A., Rebelo, A.C., Melo, C., Madeira, P., Cordeiro, R., Meireles, R., Bagaço, L., Hipólito, A., Uchman, A., da Silva, C.M., Cachão, M., Madeira, J., 2015. Palaeoecology, taphonomy, and preservation of a lower Pliocene shell bed (coquina) from a volcanic oceanic island (Santa Maria Island, Azores). Palaeogeogr. Palaeoclimatol. Palaeoecol. 430, 57-73.

Ayoub-Hannaa, W., Huntley, J.W., Fürsich, F.T., 2013. Significance of Detrended Correspondence Analysis (DCA) in palaeoecology and biostratigraphy: a case study from the Upper Cretaceous of Egypt. J. Afr. Earth Sci. 80, 48-59.

Azzarone, M., Rossi, V., Capraro, L., Faranda, C., Ferretti, P., Macrì, P., Scarponi, D., 2018. Early-Middle Pleistocene Benthic turnover and oxygen isotope stratigraphy from the Central Mediterranean (Valle di Manche, Crotone Basin, Italy): data and trends. Data in Brief (submitted).

Barbieri, G., Vaiani, S.C., 2018. Benthic foraminifera or Ostracoda? Comparing the accuracy of palaeoenvironmental indicators from a Pleistocene lagoon of the Romagna coastal plain (Italy). J. Micropalaeontol. 37, 203-230.

Barra, D., 1991. Studio del Pleistocene superiore-Olocene delle aree vulcaniche campane Università degli Studi di Napoli "Federico II" (298 pp, Tesi dottorato (unpublished))

Bassetti, M.A., Carbonel, P., Sierro, F.J., Perez-Folgado, M., Jouët, G., Berné, S., 2010 Response of ostracods to abrupt climate changes in the Western Mediterranean (Gulf of Lions) during the last $30 \mathrm{kyr}$. Mar. Micropaleontol. 77 (1), 1-14.

Baucon, A., Bordy, E., Brustur, T., Buatois, L.A., De, C., Duffin, C., Felletti, F., Lockley, M., Lowe, P., Mayor, A., Mayoral, E., Muttoni, G., De Carvalho, C.N., Santos, A., Seike, K., Song, H., Turner, S., 2012. A history of ideas in ichnology. In: Knaust, D., Bromley, R.G. (Eds.), Trace Fossils as Indicators of Sedimentary Environments. Developments in Sedimentology. Vol. 64. Elsevier, Amsterdam, pp. 3-43. http://dx.doi.org/10. 1016/B978-0-444-53813-0.00001-0.

Beals, E.W., 1984. Bray-Curtis ordination: an effective strategy for analysis of multivariate ecological data. Adv. Ecol. Res. 14, 1-55.

Belanger, C.L., Garcia, M.V., 2014. Differential drivers of benthic foraminiferal and molluscan community composition from a multivariate record of early Miocene environmental change. Paleobiology 40 (3), 398-416.

Bini, M., Brückner, H., Chelli, A., Pappalardo, M., Da Prato, S., Gervasini, L., 2012. Palaeogeographies of the Magra Valley coastal plain to constrain the location of the Roman harbour of Luna (NW Italy). Palaeogeogr. Palaeoclimatol. Palaeoecol. 337, 37-51.

Bonaduce, G., Ciampo, G., Masoli, M., 1975. Distribution of Ostracoda in the Adriatic Sea LS Olschki; Taylor and Francis.

Boomer, I., Eisenhauer, G., 2002. Ostracod faunas as palaeoenvironmental indicators in marginal marine environments. In: The Ostracoda: Applications in Quaternary Research, pp. 135-149.

Breman, E., 1975. The Distribution of Ostracodes in the Bottom Sediments of the Adriatic Sea. Vrije Universiteit van Amsterdam.

Bromley, R.G., Ekdale, A.A., 1984. Chondrites: a trace fossil indicator of anoxia in sediments. Science 224, 872-875

Bruno, L., Bohacs, K.M., Campo, B., Drexler, T.M., Rossi, V., Sammartino, I., Scarponi, D., Hong, W., Amorosi, A., 2017. Early Holocene transgressive palaeogeography in the Po coastal plain (northern Italy). Sedimentology 64, 1792-1816.

Bush, A.M., Brame, R.I., 2010. Multiple paleoecological controls on the composition of marine fossil assemblages from the Frasnian (Late Devonian) of Virginia, with a comparison of ordination methods. Paleobiology 36 (4), 573-591.

Cabral, M.C., Loureiro, I.M., 2013. Overview of Recent and Holocene ostracods (Crustacea) from brackish and marine environments of Portugal. J. Micropalaeontol. 32, 135-159.

Capraro, L., Asioli, A., Backman, J., Bertoldi, R., Channell, J.E.T., Massari, F., Rio, D., 2005. Climatic patterns revealed by pollen and oxygen isotope records across the Matuyama-Brunhes Boundary in the central Mediterranean (southern Italy). Geol. Soc. Lond., Spec. Publ. 247 (1), 159-182.

Capraro, L., Consolaro, C., Fornaciari, E., Massari, F., Rio, D., 2006. Chronology of the Middle-Upper Pliocene succession in the Strongoli area: constraints on the geological evolution of the Crotone Basin (Southern Italy). In: Moratti, G., Chalouan, A. (Eds.), Tectonics of the Western Mediterranean and North Africa. Geol. Soc. Lond. Spec. Publ. 262. Geological Society, Bath, UK, pp. 323-333.

Capraro, L., Massari, F., Rio, D., Fornaciari, E., Backman, J., Channell, J.E.T., Macrì, P., Prosser, G., Speranza, F., 2011. Chronology of the Lower-Middle Pleistocene succession of the south-western part of the Crotone Basin (Calabria, Southern Italy). Quat. Sci. Rev. 30 (9), 1185-1200.

Capraro, L., Macrì, P., Scarponi, D., Rio, D., 2015. The lower to Middle Pleistocene Valle di Manche section (Calabria, Southern Italy): state of the art and current advances. Quat. Int. 383, 36-46.

Capraro, L., Ferretti, P., Macrì, P., Scarponi, D., Tateo, F., Fornaciari, E., Bellini, G., Dalan, G., 2017. The Valle di Manche section (Calabria, Southern Italy): a high resolution record of the Early-Middle Pleistocene transition (MIS 21-MIS 19) in the Central Mediterranean. Quat. Sci. Rev. 165, 31-48.

Ceregato, A., Raffi, S., Scarponi, D., 2007. The circalittoral/bathyal paleocommunities in the Middle Pliocene of Northern Italy: the case of the Korobkovia oblonga-Jupiteria concava paleocommunity type. Geobios 40 (5), 555-572.

Colalongo, M.L., Pasini, G., 1980. La Ostracofauna plio-pleistocenica della Sezione Vrica 
in Calabria (con considerazioni sul limite Neogene/Quaternario). Boll. Soc. Paleontol. Ital. 19, 44-126.

Cosentino, A., Giacobbe, S., 2006. A case study of mollusc and polychaete soft-bottom assemblages submitted to sedimentary instability in the Mediterranean Sea. Mar. Ecol. 27 (2), 170-183.

Danise, S., Holland, S.M., 2017. Faunal response to sea-level and climate change in a short-lived seaway: Jurassic of the Western Interior, USA. Palaeontology 60 (2), 213-232.

Dominici, S., 2001. Taphonomy and paleoecology of shallow marine macrofossil assemblages in a collisional setting (late Pliocene-early Pleistocene, western Emilia, Italy). PALAIOS 16 (4), 336-353.

Dominici, S., Conti, C., Benvenuti, M., 2008. Foraminifer communities and environmental change in marginal marine sequences (Pliocene, Tuscany, Italy). Lethaia 41 (4), 447-460.

Fanget, A.S., Bassetti, M.A., Fontanier, C., Tudryn, A., Berné, S., 2016. Sedimentary archives of climate and sea-level changes during the Holocene in the Rhône prodelta (NW Mediterranean Sea). Clim. Past 12 (12), 2161-2179.

Faranda, C., Gliozzi, E., 2008. The ostracod fauna of the Plio-Pleistocene Monte Mario succession (Roma, Italy). Boll. Soc. Paleontol. Ital. 47 (3), 215-267. Faranda, C., Gliozzi, E., Ligios, S., 2007. Late Miocene brackish Loxoconchidae (Crustacea, Ostracoda) from Italy. Geobios 40 (3), 303-324.

Frezza, V., Di Bella, L., 2015. Distribution of recent ostracods near the Ombrone River mouth (Northern Tyrrhenian Sea, Italy). Rev. Micropaleontol. 52 (1), 43-66.

Gliozzi, E., Grossi, F., 2008. Late Messinian lago-mare ostracod palaeoecology: a correspondence analysis approach. Palaeogeogr. Palaeoclimatol. Palaeoecol. 264 (3), 288-295.

Gliozzi, E., Pugliese, M., Alvarez Zarikian, C., 2015. Preface Ostracoda as proxies for paleoenvironmental changes. Palaeogeogr. Palaeoclimatol. Palaeoecol. 419, 1-2

Grossi, F., Gliozzi, E., Anadón, P., Castorina, F., Voltaggio, M., 2015. Is Cyprideis agrigentina Decima a good paleosalinometer for the Messinian Salinity Crisis? Morphometrical and geochemical analyses from the Eraclea Minoa section (Sicily). Palaeogeogr. Palaeoclimatol. Palaeoecol. 419, 75-89.

Head, M.J., Gibbard, P.L., 2015. Formal subdivision of the quaternary system/period: past, present, and future. Quat. Int. 383, 4-35.

Henderson, P.A., 1990. In: Estuarine and Coastal Sciences Association (Ed.), Freshwater Ostracods: Keys and Notes for the Identification of the Species. Linnean Society of

London and the Estuarine and Coastal Sciences Association.

Horne, D., Holmes, J., Viehberg, F., Rodriguez-Lazaro, J., 2012. Ostracoda as Proxies for Quaternary Climate Change. Vol. 17 (Newnes).

Horton, B.P., Engelhart, S.E., Hill, D.F., Kemp, A.C., Nikitina, D., Miller, K.G., Peltier, W.R., 2013. Influence of tidal-range change and sediment compaction on Holocene relative sea-level change in New Jersey, USA. J. Quat. Sci. 28 (4), 403-411.

Huntley, J.W., Scarponi, D., 2015. Geographic variation of parasitic and predatory traces on mollusks in the northern Adriatic Sea, Italy: implications for the stratigraphic paleobiology of biotic interactions. Paleobiology 41 (1), 134-153.

Jackson, D.A., Somers, K.M., 1991. The spectre of 'spurious' correlations. Oecologia 86 (1), 147-151

Kowalewski, M., Wittmer, J.M., Dexter, T.A., Amorosi, A., Scarponi, D., 2015. Differential responses of marine communities to natural and anthropogenic changes. Proc. R. Soc. Lond. B Biol. Sci. 282 (1803), 20142990.

Laut, L.L.M., Clemente, I.M.M.M., Belart, P., Martins, M.V.A., Frontalini, F., Laut, V.M., Gomes, A., Boski, T., Lorini, M.L., Fortes, R.R., Rodrigues, M.A.C., 2016. Multiproxies (benthic foraminifera, ostracods and biopolymers) approach applied to identify the environmental partitioning of the Guadiana River Estuary (Iberian Peninsula). J. Sediment. Environ. 1 (2), 184-201.

Ligios, S., Benvenuti, M., Gliozzi, E., Papini, M., Rook, L., 2008. Late Miocene palaeoenvironmental evolution of the Baccinello-Cinigiano Basin (Tuscany, central Italy) and new autoecological data on rare fossil fresh-to brackish-water ostracods. Palaeogeogr. Palaeoclimatol. Palaeoecol. 264 (3), 277-287.

Macrì, P., Speranza, F., Capraro, L., 2014. Magnetic fabric of Plio-Pleistocene sediments from the Crotone fore-arc basin: insights on the recent tectonic evolution of the Calabrian Arc (Italy). J. Geodyn. 81, 67-79.

Marco-Barba, J., Mesquita-Joanes, F., Miracle, M.R., 2013a. Ostracod palaeolimnological analysis reveals drastic historical changes in salinity, eutrophication and biodiversity loss in a coastal Mediterranean lake. The Holocene 23 (4), 556-567.

Marco-Barba, J., Holmes, J.A., Mesquita-Joanes, F., Miracle, M.R., 2013b. The influence of climate and sea-level change on the Holocene evolution of a Mediterranean coastal lagoon: evidence from ostracod palaeoecology and geochemistry. Geobios 46 (5), 409-421.

Marino, M., Bertini, A., Ciaranfi, N., Aiello, G., Barra, D., Gallicchio, S., Girone, A., La Perna, R., Lirer, F., Maiorano, P., Petrosino, P., Toti, F., 2015. Paleoenvironmental and climatostratigraphic insights for Marine Isotope Stage 19 (Pleistocene) at the Montalbano Jonico succession, south Italy. Quat. Int. 383, 104-115.

Marriner, N., Morhange, C., 2007. Geoscience of ancient Mediterranean harbours. Earth Sci. Rev. 80 (3), 137-194.

Martinez-Garcia, B., Rodriguez-Lazaro, J., Pascual, A., Mendicoa, J., 2015. The "Northern guests" and other palaeoclimatic ostracod proxies in the late Quaternary of the Basque Basin (S Bay of Biscay). Palaeogeogr. Palaeoclimatol. Palaeoecol. 419, 100-114.

Massari, F., Sgavetti, M., Rio, D., D'Alessandro, A., Prosser, G., 1999. Composite sedimentary record of falling stages of Pleistocene glacio-eustatic cycles in a shelf setting (Crotone basin, south Italy). Sediment. Geol. 127 (1), 85-110.

Massari, F., Rio, D., Sgavetti, M., Prosser, G., D'Alessandro, A., Asioli, A., Capraro, L., Fornaciari, E., Tateo, F., 2002. Interplay between tectonics and glacio-eustasy: Pleistocene succession of the Crotone basin, Calabria (southern Italy). Geol. Soc. Am. Bull. 114 (10), 1183-1209.

Massari, F., Capraro, L., Rio, D., 2007. Climatic modulation of timing of systems-tract development with respect to sea-level changes (middle Pleistocene of Crotone,
Calabria, southern Italy). J. Sediment. Res. 77 (6), 461-468.

Massari, F., Prosser, G., Capraro, L., Fornaciari, E., Consolaro, C., 2010. A revision of the stratigraphy and geology of the south-western part of the Crotone basin (Southern Italy). Ital. J. Geosci. 129, 353-384.

Mazzini, I., Goiran, J.P., Carbonel, P., 2015. Ostracodological studies in archaeological settings: a review. J. Archaeol. Sci. 54, 325-328.

Mazzini, I., Rossi, V., Da Prato, S., Ruscito, V., 2017. Ostracods in archaeological sites along the Mediterranean coastlines: three case studies from the Italian peninsula. In Williams, M., Hill, T., Boomer, I., Wilkinson, I.P. (Eds.), The Archaeological and Forensic Applications of Microfossils: A Deeper Understanding of Human History. The Micropalaeontological Society Special Publications, Geological Society, London, pp. 121-142.

McCune, B., Grace, J.B., Urban, D.L., 2002. Analysis of Ecological Communities. Vol. 28 MjM software design, Gleneden Beach

Montenegro, M.E., Pugliese, N., 1996. Autoecological remarks on the ostracod distribution in the Marano and Grado Lagoons (Northern Adriatic Sea, Italy). Boll. Soc. Paleontol. Ital. 3, 123-132.

Murray, J.W., 2006. Ecology and Applications of Benthic Foraminifera. Cambridge University Press.

Negri, A., Amorosi, A., Antonioli, F., Bertini, A., Florindo, F., Lurcock, P.C., Marabini, S. Mastronuzzi, G., Regattieri, E., Rossi, V., Scarponi, D., Taviani, M., Zanchetta, G., Vai, G.B., 2015. A potential global boundary stratotype section and point (GSSP) for the Tarentian Stage, Upper Pleistocene, from the Taranto area (Italy): results and future perspectives. Quat. Int. 383, 145-157.

Pascual, A., Rodriguez-Lazaro, J., Martín-Rubio, M., Jouanneau, J.M., Weber, O., 2008. A survey of the benthic microfauna (foraminifera, Ostracoda) on the Basque shelf, southern Bay of Biscay. J. Mar. Syst. 72 (1), 35-63.

Patzkowsky, M.E., Holland, S.M., 2012. Stratigraphic Paleobiology: Understanding the Distribution of Fossil Taxa in Time and Space. University of Chicago Press (256 pp).

Pint, A., Frenzel, P., Horne, D.J., Franke, J., Daniel, T., Burghardt, A., Wennrich, V., 2015 Ostracoda from inland waterbodies with saline influence in Central Germany: implications for palaeoenvironmental reconstruction. Palaeogeogr. Palaeoclimatol. Palaeoecol. 419, 37-46.

Rio, D., Channell, J.E.T., Massari, F., Poli, M.S., Sgavetti, M., D'alessandro, A., Prosser, G., 1996. Reading Pleistocene eustasy in a tectonically active siliciclastic shelf setting (Crotone peninsula, southern Italy). Geology 24 (8), 743-746.

Ritter, M.N., Erthal, F., 2013. Fidelity bias in mollusk assemblages from coastal lagoons of southern Brazil. Revista Bras. Paleontol. 16 (2), 225-236.

Roda, C., 1964. Distribuzione e facies dei sedimenti Neogenici nel Bacino Crotonese. Geol. Romana 3 (1964), 319-366.

Rossi, S., Sartori, R., 1981. A seismic reflection study of the external Calabrian Arc in the northern Ionian Sea (eastern Mediterranean). Mar. Geophys. Res. 4 (4), 403-426. Rossi,

V., Amorosi, A., Sarti, G., Mariotti, S., 2017. Late Quaternary multiple incisedvalley systems: an unusually well-preserved stratigraphic record of two interglacial valley-fill successions from the Arno plain (northern Tuscany, Italy). Sedimentology 64, 1901-1928.

Scarponi, D., Kowalewski, M., 2004. Stratigraphic paleoecology: bathymetric signatures and sequence overprint of mollusk associations from upper Quaternary sequences of the Po Plain, Italy. Geology 32 (11), 989-992.

Scarponi, D., Kowalewski, M., 2007. Sequence stratigraphic anatomy of diversity patterns: Late Quaternary benthic mollusks of the Po Plain, Italy. PALAIOS 22 (3), 296-305.

Scarponi, D., Huntley, J.W., Capraro, L., Raffi, S., 2014. Stratigraphic paleoecology of the Valle di Manche section (Crotone Basin, Italy): a candidate GSSP of the Middle Pleistocene. Palaeogeogr. Palaeoclimatol. Palaeoecol. 402, 30-43.

Scarponi, D., Azzarone, M., Kusnerik, K., Amorosi, A., Bohacs, K.M., Drexler, T.M., Kowalewski, M., 2017. Systematic Vertical and Lateral Changes in Quality and Time Resolution of the Macrofossil Record: Insights from Holocene Transgressive Deposits, Po Coastal plain, Italy. Marine and Petroleum Geology.

Sciuto, F., Meli, A., 2015. Ostracod association from Pleistocene sediments along the Ionian coast of SE Sicily. Boll. Soc. Paleontol. Ital. 54 (3), 229-241.

Sciuto, F., Rosso, A., 2008. Distribution pattern of deep-water ostracod assemblages from Lower Pleistocene sediments from Furnari, Sicily. Boll. Soc. Paleontol. Ital. 47 (1), 33 Sciuto, F., Rosso, A., Sanfilippo, R., Maniscalco, R., 2015. New Faunistic Data on the Pleistocene Environmental Evolution of the South-Western Edge of the Hyblean Plateau (SE Sicily). Carnets de Geologie-Notebooks on Geology.

Speranza, F., Macrì, P., Rio, D., Fornaciari, E., Consolaro, C., 2011. Paleomagnetic evidence for a post-1.2 Ma disruption of the Calabria terrane: consequences of slab breakoff on orogenic wedge tectonics. Geol. Soc. Am. Bull. 123, 925-933. http://dx. doi.org/10.1130/B30214.1.

Tomašovýtch, A., Gallmetzer, I., Haselmair, A., Kaufman, D.S., Vidovic, J., Zuschin, M 2017. Stratigraphic unmixing reveals repeated hypoxia events over the past $500 \mathrm{yr}$ in the northern Adriatic Sea. Geology 45, 363-366.

Tyler, C.L., Kowalewski, M., 2014. Utility of marine benthic associations as a multivariate proxy of paleobathymetry: a direct test from recent coastal ecosystems of North Carolina. PLoS One 9 (4), e95711.

Van Dijk, J.P., 1994. Late Neogene kinematics of intra-arc oblique shear zones: the Petilia-Rizzuto Fault Zone (Calabrian Arc, Central Mediterranean). Tectonics 13, 1201-1230.

Whatley, R.C., 1990. Ostracoda and global events. In: Whatley, R.C., Maybury, C. (Eds.), Ostracoda and Global Events. Chapman and Hall, London, pp. 3-24.

Wittmer, J.M., Dexter, T.A., Scarponi, D., Amorosi, A., Kowalewski, M., 2014 Quantitative bathymetric models for late Quaternary transgressive-regressive cycles of the Po Plain, Italy. J. Geol. 122 (6), 649-670.

Yasuhara, M., Hunt, G., Cronin, T.M., Hokanishi, N., Kawahata, H., Tsujimoto, A Ishitake, M., 2012. Climatic forcing of Quaternary deep-sea benthic communities in the North Pacific Ocean. Paleobiology 38 (1), 162-179. 